\title{
DEBATES
}

\section{Os PCs e a questão democrática: discussões acerca da democracia nos partidos comunistas no Brasil}

\author{
The CPs and the democratic question: discussions on democracy in \\ communist parties in Brazil
}

\section{César Alessandro Sagrillo Figueiredo}

\section{Resumo}

A centralidade da questão democrática norteou as discussóes do PCB a partir da Declaração de Março de 1958, servindo como tese para o V Congresso do PCB em 1960. Como reflexo desta nova diretriz partidária fomentou a secção dos comunistas no Brasil entre o PCB e o PCdoB. Sendo que, em face da ditadura militar houve um longo período de transição para a democracia no Brasil, ocasionando que ambos os partidos buscassem como tática política o fim do regime militar através de uma transição conservadora e pactuada. Portanto, este artigo possui como objetivo discutir como se processou a influência da questão democrática na política dos partidos comunistas do Brasil. Quanto aos procedimentos metodológicos, tratar-se-á de um trabalho qualitativo, pois visa a reconstituição histórica procurando examinar comparativamente os PCs, através de bibliografias referentes aos elementos mais significativos do contexto internacional e nacional.

\section{Palavras-chave}

Partidos Comunistas; Declaração de Março; Transição Democrática.

\begin{abstract}
The centrality on the democratic question guided PCB discussions from the Declaration of March 1958, serving as thesis for the Fifth PCB Congress in 1960. As a reflection of this new party guideline fomented the section of communists in Brazil between PCB and PCdoB. So, in the face of the military dictatorship, there was a long period of transition to democracy in Brazil, caused both parties to seek as a political tactic the end of the military regime through a conservative and agreed transition. Therefore, this article aims to discuss how the influence of the democratic question in the political of the communist parties of Brazil was processed. As for the methodological procedures, it will be a qualitative work, since it aims the historical reconstitution seeking to examine comparatively the PCs, through bibliographies referring to the most significant elements of the international and national context.
\end{abstract}

\section{Keywords}

Communist Parties; Declaration of March; Democratic Transition. 


\section{Introdução}

O Partido Comunista do Brasil (PCdoB) e o Partido Comunista Brasileiro (PCB) são os partidos mais antigos do Brasil, ambos disputando o legado histórico do velho partido comunista (PC) fundado em 1922. Tal secção na seara comunista foi fomentada por vários fatores conjunturais no cenário político da década de 1950, tanto no espectro nacional quanto internacional, entre esses fatores destacamos a importância da questão democrática, servindo como argumento teórico para as discussões candentes do período. No entanto, o caminho dos comunistas foi extremamente tortuoso, cerceados por uma ditadura militar que durou 21 anos e que liquidou muito dos seus quadros políticos, fazendo com que os comunistas aprendessem a elaborar a sua política nas brechas da legalidade consentida e com isto buscarem os melhores caminhos para uma transição para a democracia no Brasil.

Partindo deste enfoque inicial, este artigo apresenta o seguinte questionamento proposto: qual a influência da questão democrática nas diretrizes políticas dos Partidos Comunistas no Brasil? Tal questão pode ser vista desde a década de 50 e, especialmente, pela ênfase destes partidos por uma transição pactuada e conservadora com o regime militar (1964-1985), principalmente após anos 70, uma vez que insistiriam nesta tática política para uma retomada da democracia no Brasil. A partir destes questionamentos construímos como hipótese que houve a substituição da luta estratégica pelo socialismo por uma acomodação política partidária numa democracia liberal, e com isto prevalecendo o reformismo nas hostes do comunismo brasileiro.

Com o intuito de responder a esta pergunta, cabe-nos investigá-la buscando os seguintes marcos temporais em que houve, de fato, uma inflexão nas questões democráticas e que influenciaram a linha política partidária: 1) a conjuntura política da década de 50, que serviu como moldura para a construção da Declaração de Março, diretriz política que se consagrou no V Congresso do Partido, em 1960, fomentando uma primeira secção dos comunistas no Brasil; e 2) a conjuntura política da ditadura militar que consolidou a tática democrática dos comunistas do final dos anos 1970 para 1980, tal premissa tinha como objetivo buscar uma saída consentida do regime militar.

Torna-se importante frisar que este artigo possui como objetivo principal analisar as linhas tático-estratégicas dos comunistas, especialmente a partir dos anos 1950 com ênfase na questão democrática das suas diretrizes partidárias. Realçamos que não se trata de analisar o debate da cultura democrática interna entre a elite dirigente e as suas bases, mas sim objetivar acerca dos encaminhamentos políticos que 
os comunistas procuraram dar a fim de responder as adversidades da conjuntura nacional dos anos 1950 até anos 1980. Ainda, consideramos que além das influências da política nacional para a moldura da questão democrática dentro dos Partidos Comunistas (PCs), houve também os reflexos externos que o comunismo internacional precisou enfrentar para as suas crises, especialmente nos anos $1950 \mathrm{e}$ nos anos 1980. Também, destacamos as reformulaçóes na própria matriz do pensamento comunista, tanto acerca da sua elaboração do conceito teórico de democracia quanto dos arranjos políticos que os partidos comunistas fizeram a partir dos anos 1970 sob a influência do eurocomunismo (SARTORI, 1982).

Ainda, sobre os condicionantes destas influências, mais especificamente o nacional versus o internacional, salientamos a guisa de introdução que grande parte dos autores oscila ora por uma vertente historiográfico-política, dando peso sobremaneira para a questão internacional, ora para as questôes nacionais, atrelando a esta última os dilemas sobre reforma, ditaduras, luta pela liberdade e democracia. No entanto, ponderamos a este respeito e seguimos algumas indicações profícuas a respeito de buscar uma categoria mediana, ou seja, compreendendo a existência real deste caráter dual (embora, muitas vezes, tenso) no seio do marxismo brasileiro. Dualidade que implica na tensão constante entre revolução ou reforma, justamente como reflexo desse filtro interpretativo entre a conjuntura nacional e a internacional. Quanto aos procedimentos metodológicos, tratar-se-á de um trabalho qualitativo, pois visa à reconstituição histórica procurando examinar comparativamente os PCs, com maior ênfase, entre os anos 1950 e 1980. Para a consecução deste artigo, trabalharemos com as bibliografias referentes aos elementos mais significativos do contexto internacional e nacional que busquem aludir à questão proposta. 


\section{Conjuntura politica da década de 50 e a Declaração de Março}

No tocante ao surgimento do Partido Comunista em nosso país, este surge como reflexo das lutas surgidas no Brasil no final do século XIX e início do século $\mathrm{XX}$, principalmente entre grupos socialistas dispersos e elementos do anarcosindicalismo, muito fortes no período. Também, é relevante destacar a força motriz e a influência impulsionadora da Revolução de Outubro de 1917, na Rússia, como exemplo para a consecução de um partido com caráter comunista na cena política brasileira, sendo este fundado em 1922. Quanto a esta bricolage entre referenciais teóricos distintos e experiências militantes em frentes diferenciadas, foi uma situação análoga a outros países do mundo, pois o bolchevismo se mostrou mais apto a abrigar a ânsia militante do período, justamente em face do sucesso da Revolução de Outubro (AGOSTI, 1988).

Quanto ao marco de formação do Partido Comunista no país, primeiramente, torna-se relevante esclarecermos o seguinte: o partido nasce com o nome oficial de Partido Comunista do Brasil e utiliza-se institucionalmente ao longo do seu percurso, inclusive em eleiçôes, da sigla PCB. Convém registrar que no imediato à fundação do $\mathrm{PCB}$, foram enviados a Moscou emissários para solicitar inclusão partidária na III Internacional Comunista - não obtendo o reconhecimento de pronto, justamente por esse caráter egresso do anarquismo, ainda, difuso. No entanto, em 1924 o PCB conseguiu o seu ingresso no V Congresso da Internacional Comunista.

Durante esse percurso inicial o PCB funcionou como uma sucursal do Partido Comunista da Uniấo Soviética (PCUS), caudatário em sua política das diretrizes da III Internacional Comunista. Salientamos que os comunistas de toda a América Latina, somente em 1928, com a VI Conferência da Internacional Comunista, teriam um plano elaborado para as suas respectivas seções latinoamericanas. Sendo que, é importante frisar que nesta Conferência há a caracterização política de todos os países da regiâo como países coloniais, semi-dependentes e semifeudais ou feudais, fazendo com que tal programa implicasse numa linha táticoestratégica de libertação nacional (ZAIDAN, 1991).

Neste ínterim, há o advento do ingresso de Prestes e seus tenentes no PCB. Prestes se encontrava exilado na Bolívia, sendo que houve a articulação com o PC argentino, a fim de cooptá-lo para as hostes comunistas, bem como houve uma frutífera estadia na URSS que visou prepará-lo e mediar a sua entrada no PCB. Tal ingresso, portanto, daria uma coloração um tanto mais militarista no nascente partido, pois segundo Leôncio Rodrigues (1983, p. 371), no texto O PCB: os 
dirigentes e a organização, o ingresso de Prestes produziu impacto profundo para a agremiaçáo comunista, uma vez que com ele "vieram os militares que posteriormente assumiram posições de comando no Partido, produzindo essa mistura de stalinismo e tenentismo que caracterizou o PCB nos anos subsequentes". Nos anos 30, é criada a ANL (Aliança Nacional Libertadora), fazendo com que este conjunto de lutas políticas e adesões, na década de 30, refletissem de forma consubstancial na ampliação da base partidária, assim como, na sua rede de influência: "Com Prestes e os militares, e a formação da Aliança Nacional Libertadora, o PCB estendeu sua influência às camadas intermediárias da sociedade brasileira" (RODRIGUES, 1983, p. 371 ).

Podemos enfatizar que este processo de incorporaçáo dos militares ao PCB trouxe uma caracterização sui generis à agremiação partidária, uma vez que este partido deixava de ter uma forte expressáo na classe operária - como era o seu intuito, de acordo com o corolário do marxismo-leninismo, tornando-se, por conseguinte, um partido com nítida expressão militarista nacionalista. Essa configuração carreava para dentro do partido, obviamente, as discussóes candentes dos militares tenentistas e com isto, a sobrevalorização do caráter nacional incluso no discurso do PCB: associando o nacional ao conceito de moderno e o progresso necessário à sociedade brasileira (WERNECK VIANNA, 1988).

Quanto a ANL, esta fora criada como uma frente de esquerda após a Constituição de 1934, que ainda permitia a organização partidária, e seu objetivo foi de se organizar eleitoralmente fazendo oposição a Getúlio Vargas. Destaca-se a tentativa de insurreição que fora denominada Intentona Comunista, promovido pela ANL e com apoio do PCB. Porém fracassaram, fazendo com que os líderes da ANL e do PCB começassem a ser perseguidos e presos e tendo que ficar na mais completa ilegalidade: o partido fora destroçado com a prisão dos seus líderes, inclusive Prestes. Portanto, somente após o governo de Vargas (1930-1945) é que finalmente o PCB conseguiria a sua legalidade, proporcionando aos mesmos uma grande ascensão partidária nas primeiras eleições do período de redemocratização e tornando-se no período um partido de massa ${ }^{1}$ (AARÃO REIS FILHO, 2002).

\footnotetext{
${ }^{1}$ Segundo Aarão Reis Filho (2002, p. 73), “os resultados positivos vieram com as eleiçóes nacionais, em dezembro daquele ano: o candidato apoiado pelos comunistas, Yedo Fiúza, praticamente desconhecido antes de ser lançado, apenas um mês antes das eleições, foi sufragado com cerca de $10 \%$ dos votos válidos em escala nacional. A proporção seria muito mais alta se se considerassem apenas os grandes centros urbanos, onde, efetivamente, foi possível ao partido realizar campanha eleitoral. Além disso, os
} 
No entanto, a legalidade foi provisória, pois com os reflexos dos primeiros anos da Guerra Fria o partido comunista foi posto novamente na ilegalidade, fazendo com que os seus líderes parlamentares perdessem os seus mandatos. Seus oponentes enfatizavam que o PCB servia aos interesses da Uniâo Soviética com suas ideias comunistas, alegavam acerca da deficiência do patriotismo partidários e que eram teleguiados por uma potência estrangeira (KONDER, 1980). Tal debate e confronto versavam até mesmo no nome oficial do partido, como se esse fosse uma sucursal do comunismo soviético, pois argumentavam que Partido Comunista do Brasil dava a entender que seria apenas a ramificação de um partido internacional, levando o Congresso Nacional a criar uma lei que proibia partidos de origem estrangeira. Não satisfeito em colocar os comunistas na ilegalidade, o próximo passo do governo Dutra (1946-51), que fora Ministro da Guerra durante a II Guerra Mundial no período Vargas, foi justamente romper relaçôes com a URSS, aprofundando a ideologia da Guerra Fria ${ }^{2}$ e o combate ao comunismo no Brasil.

Assim, no imediato à cassação do mandato do partido, este se volta para uma via revolucionária mais esquerdizante, que ficou conhecida através do Manifesto de Agosto, conduzido pela tática de Frente Democrática de Libertação Nacional (FDLN). Este manifesto traria subsídios às diretrizes políticas do IV Congresso do $\mathrm{PCB}$, no qual enfatizava que a independência nacional se daria com a derrubada do governo feudal-burguês, através de uma estratégia insurrecional de libertação, democrática e popular. De acordo com Rodrigues, (1996, p. 415-416), “a linha do Manifesto de Agosto foi em grande parte uma consequência de transformações que ocorreram na política internacional, com o início da guerra fria”.

Porém, as turbulências no cenário político nacional seriam sentidas na seara comunista, pois Getúlio Vargas assume novamente o governo do Brasil em 1950, mas suicida-se em agosto de 1954, fazendo com que a linha política do IV Congresso seja posta discretamente de lado, sem maiores autocríticas. Começa neste período uma "redescoberta" da política nacional, sendo amainada a linha política esquerdista. $\mathrm{Ou}$ seja, mesmo havendo uma diretriz teórica mais revolucionária no IV Congresso; no entanto, na prática os comunistas através da sua base sindical começariam a construir

comunistas elegeram 14 deputados para a Assembleia Constituinte e consagraram Luiz Carlos Prestes, eleito senador pelo Distrito Federal e deputado por mais três estados".

2 "Com a eclosão da Guerra Fria, em 1947, os governos latino-americanos adotaram políticas anticomunistas, frequentemente para ganharem o apoio dos Estados Unidos; e consequentemente, todas as naçôes, exceto três (Argentina, México e Uruguai), que tinham reconhecidos a Uniấo Soviética, romperam relaçóes com ela” (CHILCOTE, 1982, p. 281). 
um trabalho mais sistemático em comunhão orgânica com outras organizaçôes políticas, principalmente, o Partido Trabalhista Brasileiro (PTB) (SANTANA, 2001). Conforme podemos atestar o PCB sofria a todo o momento os revezes na sua política, tanto da conjuntura nacional quanto internacional. Acerca desse dilema da adequação de conjuntura, bem como da opção entre reformismo ou revolução, Leôncio Rodrigues (1983) enfatizava o seguinte:

Este dilema "reforma ou revolução", conjugado à contradição
"nacionalismo" vs. "internacionalismo proletário", dificulta a elaboração
de uma linha política mais adequada a meio brasileiro. Embora,
paradoxalmente, esta mistura de nacionalismo e "internacionalismo", de
reformismo e revolucionarismo, consiga atrair para o PCB segmentos
diferentes da população orientados por motivaçôes variadas, ela mantém
o Partido num estado de constante tensão interna e tem permanecido na
raiz das sucessivas crises e cisóes que marcaram a vida do PC no Brasil
(RODRIGUES, 1983, p. 443).

Ainda, podemos dizer que além desta questão nacional, outro fato de fundamental importância assume proporçóes gigantescas na seara comunista com os reflexos do XX Congresso do Partido Comunista da União Soviética (PCUS), de 1956. Neste Congresso vêm à tona os crimes atribuídos a Stalin, outrora dirigente máximo da URSS. Neste período, com o falecimento de Stalin, o seu sucessor Kruschev divulga o que ficou conhecido como relatório "secreto", que em linhas gerais visava um acerto de contas com o passado e denunciava os crimes atribuídos a Stalin. Este relatório seria o motivo da primeira fissura nos países comunistas, e como era de esperar, um verdadeiro terremoto nos partidos comunistas ao redor do mundo, uma vez que Stalin era a grande figura do comunismo internacional.

Obviamente, o $\mathrm{PCB}$ como tributário do marxismo-leninismo não sairia imune desses dilemas internos, sendo acionado mais intensamente após as denúncias do XX Congresso, que chegaria como uma bomba na imprensa comunista, dando fôlego para as futuras cisões. No tocante a esta questão, podemos dizer que um ajuste de contas atingiria o Comitê Central (CC), pois a direção seria responsabilizada pelos desacertos que ocorreu na política do partido, tanto pela política frentista conciliadora pós-Vargas quanto pela política esquerdizante no período de Dutra, pois ambas não vicejaram. Como era de se esperar o CC não sairia ileso sobrando acusaçōes até mesmo para Prestes (AARÃO REIS FILHO, 2002). 
Nesta conjuntura política transcorre o governo nacional desenvolvimentista de Juscelino Kubitschek, iniciado em 1956, ocorrendo um abrandamento da perseguição aos comunistas e trazendo uma falsa "legalidade" aos seus personagens principais. Tal conjuntura nacional realçaria a questão nacionalista, transformando a mesma numa verdadeira pedra de toque da política do período, fazendo com que os comunistas absorvam-na em sua linha política partidária. Além da questão nacional, começaria a somar e ganhar relevo outro conceito de fundamental importância que seria as discussões a respeito da democracia, justamente como reflexo das diretrizes impulsionadas pelo PCUS e, principalmente, da conjuntura da política nacional.

O Comitê Central instituiu uma comissão secreta a fim de elaborar uma nova linha política ao partido, surgindo deste trabalho a Declaração de Março de 1958, sendo a mesma considerada um verdadeiro divisor de águas na seara dos comunistas no Brasil. Grosso modo, percebemos que a Declaraçáo de Março fora caudatária da conjunção de todas estas mudanças ocorridas nacionais e internacionais, provocadas pelos ventos da desestalinização. Sendo que, da síntese dessas contradiçóes, reproduzir-se-ia uma nova composição do Comitê Central, pois a Declaração de Março viria impregnada pelas novas diretrizes partidárias.

Devemos frisar neste aspecto que a linha política do PCUS pregava a transição pacífica ao socialismo e, nesta perspectiva, o modelo político do PCB estava sendo gestada pari passu entre a política nacionalista e as influências externas da política do PCUS. Embora seja realçado na literatura esse caráter pacífico do PCB, como reflexo programático que seria materializado no V Congresso, em 1960, devemos fazer algumas ponderaçôes, pois embora dita pacifista, a resolução política do V Congresso, apontava, também, para uma possível eventualidade de luta armada:

Os inimigos internos e externos do povo brasileiro resistirão, por todos os meios possíveis, à perda de suas posições. Em desespero de causa, tais inimigos podem recorrer à violência para impedir a ascensão das forças revolucionárias ao Poder, criando uma situação em que a revolução não teria outra possibilidade senão a de uma solução pela luta armada (CARONE, 1982, p. 221-222). 
Entretanto, é importante registrar que esta nova diretriz que se cristalizaria no $\mathrm{V}$ Congresso do PCB manteria o viés etapista da política do PCB, primeiramente nacional e democrática e depois socialista. Todavia, mudava o seu enfoque de correlação de forças, pois se associava numa clara aliança com a burguesia nacional, atribuindo a este estrato social um papel especial na luta política, pois a consideravam com força revolucionária, acreditando que ela tivesse este aporte principalmente na luta contra o imperialismo e a favor do desenvolvimento econômico nacional. Tais premissas em conjunto modificavam o caráter estratégico da revolução brasileira, que de acordo com as Declaraçóes de Março, "a revolução no Brasil, por conseguinte, não é ainda socialista, mas anti-imperialista e antifeudal, nacional e democrática" (CARONE, 1982, p. 184).

Este delineamento político seria a base para o V Congresso do partido no qual adotaria ipsis litteris a diretriz da Declaração de Março de 1958. Obviamente que a mudança radical da linha política, comparando-a com a do IV Congresso, iria ativar novas secções e justificar as rusgas internas que já existiam tanto no seio do CC quanto nas bases partidárias do PCB. Devemos destacar que nesse processo havia conflito de grupos internos dentro da agremiação comunista, principalmente, entre a outrora elite dirigente que se encontrava desvanecida pelas lutas do Relatório de Kruschev e que tentava disputar espaço com uma nova elite emergente que surgia e estava disposta a ir para o embate político. Em síntese, buscavam não somente disputar espaço, mas marcar posição frente à linha política aprovada no V Congresso: transição pacífica, protagonismo do proletariado em conjunto com a burguesia nacional e tática de Frente Única. De acordo com a declaração de Março:

A revolução no Brasil, por conseguinte, não é ainda socialista, mas antiimperialista e antifeudal, nacional e democrática. A solução completa dos problemas que ela apresenta deve levar à inteira libertaçáo econômica e política da dependência para com o imperialismo norte-americano; à transformação radical da estrutura agrária com a liquidação do monopólio da terra e das relaçóes pré-capitalistas de trabalho (...). Estas transformações removerão as causas profundas do atraso de nosso povo e criarão, com um poder das forças anti-imperialistas e antifeudais, sob a direção do proletariado, as condiçóes para a transiçáo ao socialismo, objetivo não imediato, mas final, da classe operária (CARONE, 1982, p. 184). 
Torna-se importante registrar que havia dois grupos na tribuna de debates conflitando acerca das concepçôes políticas a serem aprovadas no V Congresso, quais sejam: 1) os líderes mais esquerdistas e ainda atrelados à diretriz do IV Congresso e não afeitos a depuração stalinista do seio do $\mathrm{PCB}$, entre esse João Amazonas, Maurício Grabois, Pedro Pomar e Carlos Danieli; e 2) noutro espectro, encontrava-se a maioria encabeçada por Jacob Gorender, Mario Alves e Carlos Marighella. Porém como a cisáo no CC era nítida, a maioria ratificou as diretrizes do V Congresso sendo afiançada por Prestes. Para a minoria que insistia na linha política tributária do IV Congresso de insurreição popular, sobrava, portanto, apenas a secção partidária. Porém, os expulsos não aceitam tais decisões e começariam a atacar o novo núcleo dirigente emergido do V Congresso.

Oficialmente, em fevereiro de 1962, numa Conferência Nacional Extraordinária é reorganizado o PCdoB. Temos assim, a partir deste momento, no seio da esquerda brasileira, dois partidos comunistas consolidados. Diferentemente do que é dito por grande parte da literatura que atribui e qualifica o PCdoB como um "simples racha" sessentista do PCB, no mesmo plano que as demais dissidências surgidas no período, através da influência cubana, percebemos que o PCdoB é um elo, ou seja, um continuador do IV Congresso do PCB, uma vez que mantém a mesma linha tático-estratégica deste congresso e o modelo de revolução de libertação nacional no Brasil e pregando a luta por um governo popular e revolucionário.

Desta forma, podemos verificar que a razão da secção dos comunistas é tanto de fundo teórico no que concerne a linha tático-estratégica ativada pela conjuntura nacional quanto derivada dos acontecimentos do movimento comunista internacional, os quais galvanizaram secçôes não somente no Brasil, como também fomentou dissidências entre outros países comunistas da esfera de influência da União Soviética. Assim sendo, não é de estranharmos que o $\mathrm{PCdoB}$, em suas relaçóes externas, oportunamente, construísse a sua política internacional com a China, uma vez que não obteve o respaldo e o reconhecimento do PCUS, pois este optou pelo $\mathrm{PCB}^{3}$.

\footnotetext{
${ }^{3}$ No tocante ao conflito Sino-Soviético, no qual o alinhamento do marxismo internacional cindiu-se entre os dois países - União Soviética e China - em meados da década de 60, podemos dizer, em linhas gerais, que ocorreram pelos seguintes motivos: 1) discussóes acerca do caráter pacifista da União Soviética; 2) divergência sobre a questão dos mísseis em Cuba; 3) fim da ajuda econômica da URSS à China; e 4) Críticas, por parte da China, da exposição exagerada dos crimes de Stalin (CHILCOTE, 1982).
} 
Embora ainda estando numa clandestinidade aparente, no início dos anos 60, esse momento seria o apogeu da inserção do PCB na política nacional, pois mesmo que não participasse do curso das eleições que se desenrolava, conseguia burlar a sua ilegalidade elegendo candidatos dentro de outros partidos, especialmente o PTB, e influenciavam no jogo político durante o governo de João Goulart (1961-1964) (SEGATTO, 1995). O PCB tencionava politicamente em suas fileiras entre a reforma e a revolução: por um lado, buscava avançar nas Reformas de Base que eram impulsionadas por Goulart; e, por outro lado, buscava imprimir, na medida do possível, um caráter mais aguerrido na sua política, apoiando toda a sorte de manifestações na esperança de forçar uma radicalidade política que, de fato, não existia na política de João Goulart. Esta oscilação seria cobrada com um preço muito caro, pois o governo de Goulart não tinha a estrutura necessária para suportar tamanhas pressões que, tanto por parte do bloco de oposição ao seu governo quanto por parte da esquerda, não conseguiam compreender os curtos limites institucionais do chefe do executivo: como resultado de toda a tensão política ocorreria o Golpe Militar.

Com o Golpe Militar, em 1964, todo um trabalho profícuo que estava sendo gestado por parte da esquerda foi sepultado, pois o legado e o trabalho dos comunistas do $\mathrm{PCB}$ em diversas instâncias foram seccionados ou totalmente extirpados. O PCB ficou, num primeiro momento, ainda bastante aparvalhado com o Golpe. Obviamente que uma grande parcela de militantes não aceitou a derrota, acusando a direção do PCB de não ter preparado o partido para um possível golpe, uma vez que confiaram demais na questão nacional e democrática, assim como nas alianças com a burguesia. Porém, por parte do diminuto $\mathrm{PCdoB}$ que não confiava nos dispositivos legais do governo João Goulart, assim como estava longe de crer na burguesia, ratificava de imediato a sua posição de combatente de primeira hora da ditadura militar.

No tocante aos contornos políticos impulsionados pela corporação militar no pós 64, estes estabelecem uma série de medidas de exceçôes, destacando o AI-2 que acabava com os partidos políticos tradicionais, instituindo em 1966 apenas dois partidos: 1) a ARENA, Aliança Renovadora Nacional, partido de apoio à corporação militar; e 2) o MDB, Movimento Democrático Nacional, partido de oposição consentida pelos militares (KINZO, 1988). Portanto, as eleições vindouras, em 1966, vinham com as cartas marcadas, criando desta forma um grande descontentamento dos eleitores. O PCB apoiaria o MDB desde o seu nascedouro, vindo a formar as 
hostes partidárias desta agremiação desde o seu início com o intuito de tentar eleger parlamentares por dentro desse partido, numa tentativa de distender o regime dentro das suas próprias instâncias legais.

Devemos destacar que neste período as manifestações de massas se avolumavam nas grandes cidades, assim como uma nova militância emergia das manifestações nas ruas. O PCB mesmo com todas as adversidades manteria a mesma linha tático-estratégica no seu VI Congresso, realizado em 1967. Sendo que essa linha política com tática de Frente Única não é aceita pela maioria da militância, vindo estes a comporem as dissidências do PCB, que adotam, de acordo com as características regionais, a opção pela luta armada. Dentre essas destacamos: a Dissidência Comunista da Guanabara, que virou MR-8 e o Agrupamento Comunista de São Paulo, que virou ALN, esta dirigida por Carlos Marighela, veterano nas lutas comunistas.

No tocante ao PCdoB, este ciente dos limites de lutar pela via institucional dentro de uma ditadura militar, centrará toda a sua força no que se denominou de Guerrilha do Araguaia, no norte de Goiás e Sul do Pará, buscando encaminhar os seus primeiros militantes para a área a partir de 1966. Neste ponto podemos ver claramente a bifurcação na seara dos comunistas, pois embora um mesmo tronco, partiu-se em dois ramos bem distintos. Ainda, o PCdoB se empenharia nesta luta a partir dos cânones do maoísmo chinês: luta popular prolongada no campo, obviamente como reflexo da cisão comunista e das denúncias dos crimes de Stalin.

$\mathrm{O}$ mergulho que a esquerda daria nesse período foi denominado por Jacob Gorender de Combates nas Trevas (1987), pois o inimigo (ditadura) tinha uma força imensamente superior ao contingente da esquerda. A ditadura rapidamente soube se aparelhar através de mecanismo coercitivo, fato este que a guerrilha tomou conhecimento tardiamente. Quanto aos diversos grupos cindidos do PCB no final da década de 60, estes foram sucessivamente abatidos já no início da década de 70; evaporando, portanto, a perspectiva de tomada de poder pelas armas no que se convencionou chamar de guerrilha urbana. Quanto ao PCdoB foram localizados em 1972, durando o seu enfretamento militar até 1975 , no que se convencionou chamar de Guerrilha do Araguaia, sendo igualmente aniquilados.

Embora este mergulho nas trevas a direção do PCB da Guanabara lançaria um editorial a respeito da necessidade do aprofundamento das questôes democráticas, dando importância, neste momento, muito mais à questão da retomada da democracia do que da questão nacional, invertendo, pois a partir deste momento a linha tático-estratégica seria democrática e nacional, posteriormente, socialista. 
Porém, mesmo não optando pela luta armada e tentando insistir por uma via legal oculta dentro das instâncias do $\mathrm{MDB}$ a sua direçáo é golpeada pela repressão em meado dos anos 70, após o aniquilamento da guerrilha urbana e rural. Nesta conjuntura e a fim de preservar minimamente do extermínio parte do Comitê Central do PCB, começariam a ser encaminhados para o exílio, entre esses Prestes e outros dirigentes, os que ficaram acabaram figurando na lista de desaparecido políticos (FIGUEIREDO, 2013).

\section{Conjuntura politica no final dos anos 1970 para 1980}

Em meio a derrotas, exílios, mortes e assassinatos a esquerda brasileira começou a reorientar o seu foco em meados da década de 70. Podemos considerar como ponto de ruptura a eleição de 1974 em que, pela primeira vez, o MDB teve uma excelente votação, conseguindo em algumas regiōes do Brasil vencer a ARENA, principalmente, nos grandes centros urbanos da região Sul-Sudeste. Seria a indicação que a esquerda precisava para buscar uma nova linha política. Sendo que da parte dos egressos da luta armada seria uma reorientação tática, entre esses o PCdoB. Por parte do PCB, seria a consagração da sua linha política do VI Congresso, no qual ratificava a linha política de Frente Única de combate à ditadura militar (FIGUEIREDO, 2013).

Quanto aos egressos da esquerda armada, esses ainda eram bastante ciosos quanto aos limites do MDB enquanto veículo de combate à ditadura, no entanto, era a única alternativa legal que possuíam para se articular politicamente. Quanto ao $\mathrm{PCB}$ se sentiam totalmente confortáveis dentro da seara do MDB, pois operacionalizavam da melhor maneira possível a sua tática pela via institucional, se autoqualificando como os grandes responsáveis pelo sucesso da via eleitoral. Sendo que, tamanha vaidade seria cobrada com igual intensidade pela ditadura militar que não o perdoou: novamente em 1975 e 1976 ocorre uma série de prisões. Por parte do PCdoB, este ainda com sequelas das mortes da Guerrilha do Araguaia foi novamente golpeado na chamada Chacina da Lapa, sendo assassinados alguns membros do Comitê Central, enquanto outros foram presos (GORENDER, 1987).

Os PCs mesmo entre prisóes conseguiriam eleger alguns deputados nas eleiçóes de 1978. Assim, os caminhos para os PCs ainda eram amargos; no entanto, conseguiam na medida do possível fazer parte da política institucional do período, elegendo deputados e vereadores. Porém, devemos relativizar o poder de inserção destes deputados, assim como a capacidade operacional na luta que tinham, pois 
viviam com ameaças de ser cassados, presos e torturados. No curso da luta do final dos anos 70 o Brasil é surpreendido pela retomada da luta sindical no ABC paulista, trazendo a tona uma nova geração de sindicalistas que emergia na luta como liderança, tornando as velhas lideranças sindicais comunistas em personagens opacos, uma vez que muitas lideranças sindicais estavam no exílio, ou mesmo presas (SADER, 1988).

Neste percurso a conjuntura mudava e o presidente ditador Geisel prometia uma abertura democrática lenta, segura e gradual. Os comunistas, especialmente do PCB, crendo nesta transição conservadora, afiançada pela ditadura, pactuam este processo, não forçando o percurso, pois o intuito era que não houvesse um retrocesso na abertura democrática e mantinham a tática de Frente Única, inclusive neste momento o PCdoB. Neste processo começavam a trilhar uma tática política baseada no apoio irrestrito ao MDB, buscando eleger parlamentares pela legenda de oposiçáo oficial do governo e esperando distender o regime de forma lenta, pois estavam sempre ciosos de um possível recuo político.

Quanto às novas lideranças que emergiram no final dos anos 70, estas formariam o Partido dos Trabalhadores (PT). Ainda ocorreria a volta dos exilados políticos, em 1979, assim como a abertura das prisóes e a liberdade dos presos políticos. O cenário era bem diferente aos PCs: 1) para o PCB, que foi hegemônico até o início dos anos 60, precisava buscar recompor o curso da sua história e buscar reconstruir o seu partido a partir da volta do Comitê Central do exílio; e 2) quanto ao PCdoB, implicava buscar imprimir o seu partido no curso das lutas do período, a fim de disputar a seara da esquerda com as diversas agremiaçóes nascentes que emergiam. Devemos salientar que em 1979 ocorreu a volta do pluripartidarismo e o MDB se transformaria em Partido do Movimento Democrático Brasileiro (PMDB). Porém, sem conseguir a sua legalidade os PCs ficaram incluídos ainda dentro do PMDB (FIGUEIREDO, 2013).

Mesmo com a volta dos exilados e com a recomposição do Comitê Central do PCB esse partido estava longe de possuir uma unidade, a começar pelo CC que se encontrava cindido. Desta vez Prestes era a voz dissonante, pois o outrora dirigente que sempre buscava construir a unidade do partido endossando um centro pragmático, neste momento, dava voz contrária ao CC. O ponto de discórdia baseava-se justamente no processo de transição para a democracia no Brasil, se uma transição pactuada e conservadora ou se a perspectiva de frente popular de esquerda. A discussão explode na grande imprensa e as manchetes davam destaque das fissuras dentro do PCB. 
Diferentemente da maioria do Comitê Central, o secretário geral não concordava com a proposta de uma transição negociada para a saída do regime ditatorial. Também não concordava com a importância atribuída à burguesia na revolução brasileira. Ao invés de uma "frente democrática" para derrubar o regime, propunha uma "frente de esquerda" (PANDOLFI, 1995, p. 219).

O rompimento de Prestes não poderia passar incólume, pois geraria uma séria fratura no PCB. Prestes saiu do PCB e levou consigo um expressivo contingente de militantes; porém, não vindo a formalizar nenhuma agremiação partidária. Quanto ao PCB, "indiferente" a saída de Prestes, endossava uma perspectiva teórica renovadora aprofundando ainda mais a sua tática de Frente Única derivada ainda do VI Congresso do Partido, endossando-as nas eleições vindouras no PMDB. Sobre os renovadores cumpre explicitar que estes traziam para o PCB muitas discussóes prementes na seara política internacional, principalmente acerca da distinção da democracia burguesa e da democracia socialista. Neste sentido, procuravam romper com alguns pressupostos mais ortodoxos pecebistas, assim como a questão da revolução em duas etapas, primeiramente democrática e nacional e posteriormente socialista. Obviamente, que tais discussões estavam longe teoricamente do CC e do grosso da militância, não que este partido não estivesse apto para uma concepção política com um refinamento teórico mais apurado, mas outras questóes irrompiam nas hostes comunistas, principalmente amainar a cisão de Prestes.

No tocante a questão teórica ganharia destaque o artigo de Carlos Nelson Coutinho (1980), A democracia como valor universal. Ainda, a respeito da disputa interna, segundo Coutinho, num primeiro momento os comunistas com concepções teóricas gramscianas unem-se ao CC para derrotar o ultradogmatismo de Prestes, sendo que, num segundo momento, "a direção não hesitou em transformar os 'grasmcianos' numa pretensa 'direita' que deveria ser derrotada depois que a 'esquerda' prestista já o tivesse sido” (COUTINHO, 1980, p. 162). Convém explicitar que embora alijando da sua agremiação esta ala renovadora, o PCB logrou, oportunamente, aproveitar essas discussões teóricas nas suas proposiçôes políticas a 
partir do VII Congresso ${ }^{4}$. Sobre $A$ democracia como valor universal, que vicejaria no partido ao longo da década de 80, Coutinho (1980) em seu texto explicita:

De modo esquemático, poderíamos dizer que as tarefas de renovação democrática desdobram-se em dois planos principais. Em primeiro lugar, trata-se de conquistar e depois consolidar um regime de liberdades fundamentais, para o que se torna necessária uma unidade com todas as forças interessadas nessa conquista e na permanência das "regras do jogo" a serem implantadas por uma Assembleia Constituinte dotada de legitimidade. E, em segundo, trata-se de construir as alianças necessárias para aprofundar a democracia no sentido de uma democracia organizada de massa, com crescente participação popular; e, nesse nível, a busca da unidade terá como meta a conquista do consenso necessário para empreender medidas de caráter antilatifundiário e antimonopolista e, numa etapa posterior, para a construção em nosso País de uma sociedade socialista fundada na democracia política (COUTINHO, 1980, p. 4041).

No tocante ao PCdoB, endossa, assim como o seu coirmão comunista, a ênfase na tática democrática pelo PMDB, mas sem abrir mão, segundo eles, da estratégia final socialista, baseado ainda na VII Conferência do PCdoB de 1979. No entanto, no mesmo documento apontava para a amplitude das forças democráticas:

Unir as mais amplas forças políticas sociais em torno de bandeiras democráticas e populares a fim de travar a luta contra o governo e o regime que ele representa. Propugnar a organização de uma ampla frente democrática em escala nacional que agrupe todas as forças de oposição, e trabalhar pela sua concretização. Dentro dela contribuir para articular e fortalecer a oposição popular como seu núcleo mais ativo e combater todas as restriçóes ao crescimento do movimento de massas ou as discriminaçóes, tendo em vista unir a classe operária e despertar para a luta as grandes massas camponesas. (PCdoB, 1979).

\footnotetext{
${ }^{4}$ A partir do VII Congresso, de certa forma, esta teoria democrática se encaixaria na linha política do PCB. Nas palavras de Pandolfi (1995, p. 224): “no VII Congresso, as teses democráticas foram incorporadas de forma ambígua, produzindo uma acomodação oportunista com as teses de inspiração opostas".
} 
Ou seja, a linha política estava definida, pois ambos os partidos insistiriam na tática da mais ampla frente política de combate à ditadura dentro do PMDB. Ainda, devemos destacar que em 1982 ocorreria uma eleição decisiva, pois seria a eleição que escolheria o novo Presidente civil do Brasil, através do Colégio Eleitoral a ser realizado em 1984. Em síntese, a ditadura poderia ser posta definitivamente em xeque nesta eleição, servindo, portanto, como uma antessala para a transição à democracia. Porém, os caminhos até a eleição seriam tortuosos, pois a ditadura iria driblar o cenário político com uma série de medidas oportunistas, que primavam por privilegiar a ditadura no cenário eleitoral (MENEGHELLO, 1988).

Com este intuito foi elaborado o Pacote de Novembro, o qual previa uma série de alteraçôes legais que teriam peso no processo eleitoral de 1982: 1) proibiamse as alianças partidárias; e 2) exigia-se que os partidos lançassem candidatos a todos os cargos que se encontravam em disputa, governador do estado, senador, deputados estaduais, vereadores e prefeito, sendo que tornava-se explícito a vinculação do voto do plano local ao nacional, sob pena de anulação do voto. Neste processo, as organizaçóes comunistas vinculadas com o PMDB possuíam a palavra de ordem do voto útil e democrático, a fim de buscar ganhar as eleiçóes do período, fazendo com que as teses do PMDB caiam perfeitamente aos anseios do PCB, segundo Pandolfi:

De acordo com as teses defendidas nos anos 80, o único caminho possível para atingir o socialismo no Brasil era através de uma democracia de massas, organizada de baixo para cima, centrada nas diversas formas de organização da população. Consolidar as instituiçôes da democracia política era uma tarefa prioritária. O partido procurava se desvencilhar de um passado comprometido com uma concepção "golpista", "elitista" e "radical” sobre o processo de transformação da sociedade brasileira. A ideia de tomada brusca do poder, presente ao longo de várias décadas, foi sendo gradativamente substituída pela proposta de revolução processual (PANDOLFI, 1995, p. 121).

Assim, através desta tática de Frente Única, os PCs acabariam perdendo o seu espaço para os novos atores que surgiam na luta contra a ditadura, principalmente $o$ PT. Neste período era visível a ascensão do PT, principalmente no meio sindical, ambiente que deveria ser a seara principal dos comunistas, ou seja, no seio da classe operária. Segundo Marco Aurélio Santana (2001), este espaço fora ocupado pelo PT, justamente pela política de transição conservadora dos PCs. 
A luta contra o arrocho, pilar da política econômica da ditadura militar, teria centralidade. O restante ("sem inserção na massa") viria com a luta e a consolidação da democratização. Aqui, fica indicado um dos pontos que, em breve, distanciarão grandemente os comunistas desses "novos atores". Esse etapismo propugnado pelo PCB o empurrava contra certas demandas e propostas em debate no movimento sindical (SANTANA, 2001, p. 192).

Ainda, segundo Santana (2001), com a opção pela transição conservadora os PCs perdiam influência no meio sindical deixando espaço para o PT se consolidar como o real partido de oposição da seara da esquerda brasileira, vide as greves do período. Também, o autor enfatiza que o motivo que acarretou este descenso dos PCs foi o apoio destes aos sindicatos tradicionais, tidos como pelegos e criando uma ruptura no mundo sindical. Portanto, devemos enfatizar que esta ruptura era reflexo da linha tático-estratégica dos PCs, fato este que criaria mais atraso para os comunistas em um dos principais focos de luta da década de 80 .

Com o término da ditadura militar, em 1985, houve a passagem ao governo civil de José Sarney e os PCs conquistam a sua legalização partidária. Porém, os comunistas ficaram muito aquém no seu processo de consolidação partidária, justamente pelo atraso da legalização do seu partido, além deste motivo tinham poucos parlamentares comunistas eleitos, fato este que, de certa forma, dificultava a sua consolidação e sua inserção na grande política partidária. Ainda, com o advento da Nova República, os comunistas optaram pelo apoio ao governo Sarney, a fim de garantir a efetiva transição democrática e apoiando este governo nos planos econômicos (SANTANA, 2001). Tais fatos fariam com que os comunistas perdessem a sua identidade com a principal classe que eles gostariam de ser identificados: a classe operária. Para o PCB, o fim era sintomático:

O PCB revivia com muita intensidade o dilema que atingia todos os partidos que se pretendiam representantes da classe operária, mas que estavam inseridos no jogo eleitoral. A escolha era entre ser um partido homogêneo em termos do apelo à classe operária, porém condenado a derrotas eleitorais, ou ser um partido que diluísse sua orientação em termos da classe operária, mas que, por isso mesmo, conseguisse êxitos eleitorais (PANDOLFI, 1995, p. 237).

Somado a esses fatos houve uma grande turbulência que abalaria definitivamente o PCB: a queda do muro de Berlim, em 1989, e o fim da URSS, em 
1991. O fim parecia próximo para o PCB. Nos dias 25 e 26 de janeiro de 1992 o PCB realizou o seu X Congresso, e ao final deste congresso o PCB foi declarado extinto e criado em seu lugar o PPS (Partido Popular Socialista) (PANDOLFI, 1995). Quanto ao PCdoB, sempre crítico do PCUS e do atrelamento a URSS parecia a grande revanche, no entanto a conjuntura arrastava também o partido rival, pois o fim da URSS quebrava o paradigma do socialismo. Era necessário mais uma vez repensar a conjuntura, bem como a tática e a estratégia a fim de ir ao encontro da realidade nacional e internacional, igualmente, era necessário ter novos modelos e inserçáo na sociedade brasileira. Nesta conjuntura o PCdoB chama para o seu VIII Congresso, reafirmando a práxis marxista-leninista, mas visando a integração definitiva na grande política brasileira (PCdoB, 2000).

Desta forma, estava posto a linha política dos herdeiros do velho partido de 1922. Devemos sublinhar que uma parcela de militantes do antigo PCB tentou retomar a antiga sigla em meados da década de 90 , sendo deste então um partido totalmente inexpressivo. No tocante ao PCdoB, também se reivindicando como herdeiro legítimo do partido fundado em 1922, ao longo da década de 90 vai trilhar um caminho de tentativa de institucionalização partidária, mas neste processo a questão de revolução se diluirá em detrimento de um discurso focado cada vez mais da ordem democrática e com o apoio tático à linha política petista, visando às vitórias eleitorais de Lula e Dilma nos anos 2000 e a sua acomodação reformista na ordem burguesa.

\section{Conclusão}

Retomando as discussóes propostas acerca da questão democrática e a sua implicância no esmorecimento de estratégia revolucionária, percebemos que na esquerda brasileira a partir da Declaração de Março de 1958, a questão democrática transformou-se em um ponto de ruptura das concepçóes política, fomentando a secção na seara dos comunistas no Brasil. Quanto ao PCB este fora tributário dos ditames de uma conjuntura internacional e nacional que propiciou a elaboração desta linha tático-estratégica e que se manteve continuamente ao longo da ditadura. Quanto ao $\mathrm{PCdoB}$, embora rompendo com esta linha política, em virtude do cerceamento da ditadura militar iria começar a compor forças com o PCB dentro do MDB-PMDB a partir dos anos 1970, elaborando também uma tática democrática, mesmo que apontasse para uma estratégia final de socialismo. 
Especificamente quanto ao $\mathrm{PCB}$, este entrará mais enfaticamente na questão democrática, realçando a "democracia como valor universal", desfocando e colocando a questão do socialismo a um futuro sine die, pesando na sua trajetória final o atrelamento excessivo a Nova República de Sarney. No entanto, com o desmoronamento do Leste Europeu, sepultou definitivamente o ideário da III Internacional Comunista no seio do PCB, tornando-se, portanto, um ponto final para a organização comunista dentro do modelo do marxismo-leninismo. No tocante ao PCdoB, tornar-se-ia, também um partido do establishment, como poderemos ver ao longo do governo Lula e Dilma (2003-2016).

Finalizando, vemos que o que aconteceu no Brasil com seus partidos comunistas não foi tão diferente do que aconteceu com os partidos comunistas nos países do capitalismo avançado. Segundo Sartori (1982) partidos que deveriam ser antissistema passaram a compor coalizóes de governo capitalista, tornando-se partidos reformistas. Assim, constatamos que ambos os partidos (em tempos diferentes) trilharam o mesmo percurso: de uma concepção revolucionária uníssona de tomada de poder para uma bifurcação reformista em dois diferentes partidos (PCB e PCdoB). Diferenças à parte, o que fica explícito é que a questão da democracia, reinterpretada como uma saída da ditadura serviu como caldo político para a suavização da questão revolucionária e servindo, inclusive como influência para outras searas da esquerda na política brasileira.

- César Alessandro Sagrillo Figueiredo é Doutor em Ciência Política, pela Universidade Federal do Rio Grande do Sul. É Professor da Universidade Federal do Tocantins. E-mail: cesarpolitika@gmail.com. 


\section{Referências}

AARÁO REIS FILHO, Daniel. Entre Reforma e Revolução: A trajetória do partido Comunista no Brasil entre 1943 e 1964. In: RIDENTI, Marcelo; AARAO REIS FILHO, Daniel (Org). História do Marxismo no Brasil. Campinas: Ed. da UNICAMP, 2002, p. 73-108.

AGOSTI, Aldo. As correntes constitutivas do movimento comunista internacional. In: HOBSBAWM, Eric (Org). História do marxismo - O marxismo na época da terceira internacional: da Internacional Comunista de 1919 às frentes populares. v. 4, Rio de Janeiro: Paz e Terra, 1988, p. 45-82.

CARONE, Edgar. O P.C.B (1943-1964). Volume II. São Paulo: Ed. Difel, 1982.

CHILCOTE, Ronald H. O Partido Comunista Brasileiro: conflito e integração. Rio de Janeiro: Ed. Graal, 1982.

COUTINHO, Carlos Nelson. A democracia como valor universal. São Paulo: Ed. Livraria Editora Ciências Humanas, 1980.

FIGUEIREDO, César Alessandro S. O impacto da crise do socialismo nos Partidos Comunistas no Brasil. 2013. 271 f. Tese (Doutorado em Ciência Política) - Programa de Pós-Graduação em Ciência Política, Universidade federal do Rio Grande do Sul, Porto Alegre, 2013.

GORENDER, Jacob. Combate nas Trevas - A esquerda brasileira: Das ilusóes perdidas à Luta Armada. São Paulo: Editora Ática, 1987.

KINZO, Maria D`Alva Gil. Oposição e Autoritarismo: gênese e trajetória do MDB - 1966/1979. São Paulo: Editora Vértice, 1988.

KONDER, Leandro. A democracia e os comunistas no Brasil. Rio de Janeiro: Graal, 1980.

MENEGUELLO, Raquel. PT: a formação de um partido (1979-1982). Rio de Janeiro: Paz e Terra, 1989.

PANDOLFI, Dulce. Camaradas e companheiros. memória e história do PCB. Rio de Janeiro: Relume-Dumará: Fundação Roberto Marinho, 1995.

PARTIDO COMUNISTA DO BRASIL. [documento histórico] Resoluçóes da $7^{\text {a }}$ Conferência. 1979. Disponível em: <http:/www.grabois.org.br/cdm/principais-documentos/148505/2009-1210/resolucoes-da-7-conferencia-do-pcdob-1979>. Acesso em 29 set. 2017.

- [documento histórico] Informe político ao VIII Congresso. In: Em defesa dos trabalhadores e do povo brasileiro. São Paulo: Ed. Anita Garibaldi, 2000.

RODRIGUES, Leôncio Martins. O PCB: os dirigentes e a organização. In: FAUSTO, Boris. (Org.).

História geral da civilização brasileira: o Brasil republicano. São Paulo: Difel, 1983, p. 363-443.

SADER, Eder. Quando novos personagens entram em cena. São Paulo: Paz e Terra, 1988.

SANTANA, Marco Aurélio. Homens partidos: comunistas e sindicatos no Brasil. São Paulo: Boitempo Editorial, 2001.

SARTORI. Giovanni. Partidos e Sistemas Partidários. Rio de Janeiro. Zahar/Brasília: UNB. 1982.

SEGATTO, José Antônio. Reforma e revolução: as vicissitudes políticas do PCB (1954-1964). Rio de Janeiro: Civilização Brasileira, 1995.

WERNECK VIANNA, Luiz. Questão Nacional e democracia: o ocidente incompleto do PCB. Série Estudos. Rio de Janeiro: IUPERJ, 1988. 
148 | César Alessandro Sagrillo Figueiredo

ZAIDÁN, Michel. O grande tourant: o VI Congresso da Internacional Comunista (1928-1929). In: AARÃO REIS FILHO FILHO, Daniel (Org.) História do Marxismo no Brasil: o Impacto das Revoluçóes, v. 4, Rio de Janeiro: Ed. Paz e Terra, 199, p. 89-104.

Texto recebido em 29 de setembro de 2017. Aprovado em 24 de novembro de 2017. 